\title{
Environmental contamination by fluoroquinolones
}

\author{
Verônica Maria Fadário Frade1, Meriellen Dias², Antonio Carlos Silva Costa Teixeira², \\ Mauri Sergio Alves Palma ${ }^{1, *}$
}

\author{
${ }^{1}$ Department of Biochemical and Pharmaceutical Technology, School of Pharmaceutical Sciences, University of São Paulo, \\ ${ }^{2}$ Department of Chemical Engineering, School of Engineering, University of São Paulo
}

\begin{abstract}
Over the past few decades, a high number of pharmaceuticals have been detected in surface, ground and drinking waters. This contamination comes from domestic sewage, livestock, hospitals and chemicalpharmaceutical industries. Typical examples of these pollutants are the fluoroquinolones - powerful antibiotics used in human and veterinary medicine. The presence of fluoroquinolones in the environment can pose a serious threat to the ecosystem and to human health due to their high consumption globally: in 1998, around 120 tons were produced. Even at low environmental concentrations, antibiotics stimulate bacterial resistance. The consequences of the presence of fluoroquinolones in the environment are not fully understood, but are known to be toxic to plants and aquatic organisms. Approximately $85 \%$ of the fluoroquinolones present in influents can be removed by conventional wastewater treatment plants, but the removed fraction is frequently accumulated in the sludge, which is sometimes used as fertilizer, representing an additional input route into the environment. The removal of fluoroquinolones by biological treatment is ineffective, and it is believed that only advanced oxidation technologies are able to destroy these emerging pollutants.
\end{abstract}

Uniterms: Fluoroquinolones/waste/environmental impact. Fluoroquinolones/waste/environmental contamination. Environmental contamination. Advanced oxidation processes/wastewater treatment.

\begin{abstract}
Nas últimas décadas, um grande número de fármacos tem sido identificado em águas superficiais, subterrâneas e potáveis. Tal contaminação advém do esgoto doméstico, hospitais, criação de animais e das indústrias químico-farmacêuticas. Exemplos típicos desses poluentes são as fluoroquinolonas potentes antibióticos empregados na medicina humana e veterinária. A presença de fluoroquinolonas no meio ambiente pode representar uma séria ameaça para o ecossistema e para a saúde humana devido ao alto consumo mundial: em 1998 foram produzidas, aproximadamente, 120 toneladas. Mesmo em baixas concentrações, antibióticos podem estimular a resistência bacteriana. As consequências da presença de fluoroquinolonas no ambiente não são completamente compreendidas, mas sabe-se que são tóxicas para plantas e organismos aquáticos. Aproximadamente $85 \%$ das fluoroquinolonas presentes em efluentes podem ser removidos em estações de tratamento de efluentes convencionais, porém a fração removida é frequentemente acumulada no lodo, muitas vezes usado como fertilizante, o que representa uma rota adicional de entrada desses compostos no ambiente. A remoção de fluoroquinolonas por meio de tratamento biológico não é eficiente, e acredita-se que somente as tecnologias de oxidação avançada sejam capazes de degradar esses poluentes emergentes.
\end{abstract}

Uniterms: Fluorquinolonas/resíduos/impacto ambiental. Fluorquinolonas/resíduos/contaminação ambiental. Contaminação ambiental. Processos oxidativos avançados/tratamento de águas residuais.

\section{INTRODUCTION}

Population growth and industrial expansion has brought with it worldwide contamination of the

\footnotetext{
*Correspondence: M. S. A. Palma. Departamento de Tecnologia Bioquímico-Farmacêutica, Faculdade de Ciências Farmacêuticas, Universidade De São Paulo. Av. Prof. Lineu Prestes, 580, Bloco 16, 05508-000, São Paulo, Brazil. E-mail: msapalma@usp.br, veronicafrade@usp.br, meriellend@gmail.com, acscteix@usp.br
}

atmosphere, soil and water. Moreover, there is growing awareness of the deterioration of the environment and of the need to reverse, or at least, mitigate this process. Issues related to the quality of water have been extensively discussed in view of this natural resource being essential to a broad spectrum of human activities, such as public and industrial supply, agricultural irrigation, electricity production, leisure and recreation activities besides aquatic life preservation (Melo et al., 2009). Pharmaceutical 
residues present in the environment have prompted studies in the industry and academia to assess the effects of bioactive compounds in the environment (Golet et al., 2002; Lin et al., 2010).

Pharmaceuticals are widely used in human and veterinary medicine to treat infections, prevent and diagnose diseases, and to promote growth and prophylaxis in livestock (Fink et al., 2012). After administration to humans and animals, a significant portion of the pharmaceuticals, from 10 to $90 \%$, is excreted in urine and feces in an unchanged form into sewage, depending on the drug (Kümmerer et al., 2000; Bila, Dezotti, 2003; Kümmerer, 2009a; Pereira et al., 2012), and subsequently enter WWTPs, where these compounds are treated, along with other organic and inorganic compounds present in the sewage (Ikehata et al., 2006; Pereira et al., 2012).

The continuous entry of drugs into the aquatic environment, even at low concentrations, may pose longterm potential risks to aquatic and terrestrial organisms (Klavarioti et al., 2009; Ikehata et al., 2006).

In 1970, the first report on pharmacologically active compounds in the water environment was published (Gosh et al., 2009), but the presence of drugs in the environment became an emerging concern only in the mid-1990s, when new analytical technologies were available (Homem, Santos, 2011).

All over the world, drugs such as antibiotics, hormones, anesthetics, antidepressants, chemotherapeutic agents, X-ray contrasts, anti-inflammatory agents (Tambosi, 2008; Ikehata et al., 2006), among others, have been detected in wastewaters, sediments and soil, as well as different water reservoirs such as surface, ground (Bila, Dezotti, 2003), drinking, tap, and ocean water at low concentration levels ranging from $\mathrm{mg} \mathrm{L}^{-1}$ to ng L-1 (Golet et al., 2002; Klavarioti et al., 2009). This fact indicates their ineffective removal from water and wastewater using conventional treatment technologies (Ikehata et al., 2006).

As antibiotics are highly bioactive compounds, there are serious concerns over their role in enhancing antibiotic resistance among pathogenic bacteria (Gosh et al., 2009), rendering current antibiotics ineffective in the treatment of numerous diseases (Homem, Santos, 2011). Antibiotics can also affect the endocrine system of fish and be toxic to algae and invertebrates (Guinea et al., 2009a, 2009b). Another aspect is that little is known about the potential chronic health effects associated with long-term ingestion of mixtures of antibiotics through drinking water (Ikehata et al., 2006), given that drugs are designed to exert an effect on specific biological systems (Fink et al., 2012).
Fluoroquinolones are often found in surface waters (Pena et al., 2007). This family of antibiotics is widely employed in human (since the 1980s) and veterinarian (since the 1990s) medicine, due to the antibiotics' rapid bactericidal action against a number of common microorganisms. Among these antimicrobials, enrofloxacin is the most used drug in veterinary medicine (Golet et al., 2002; Guinea et al., 2009a).

Fluoroquinolones are active against many pathogenic bacterial species by selectively inhibiting bacterial DNA synthesis. Administered fluoroquinolones are largely excreted as unchanged compounds in urine, and consequently discharged into hospital or municipal sewage (Golet et al., 2002; Pena et al., 2007; Fink et al., 2012). These fluoroquinolones are not completely removed at WWTPs and consequently, their continuous introduction into the environment makes fluoroquinolones 'pseudo-persistent' compounds. The fluoroquinolones, initially present in water bodies, rapidly transfer into the soil and sediments, due to strong adsorption on minerals and organic matter (Sturini et al., 2012).

Besides their potential to promote antibiotic resistance, fluoroquinolones also have an unfavorable ecotoxicity profile (Golet et al., 2002), and may contribute to a significant portion of the measured bacterial genotoxicity in hospital effluents (Zhang, Huang, 2005).

\section{HISTORICAL}

The first discovered quinolone was the nalidixic acid (Lesher et al., 1962), which showed activity only against enterobacteria (Nava, 2007). Quinolones emerged accidentally, as a by-product of an antimalarial agent synthesis, with known and proven antibacterial activity, chloroquine. Because nalidixic acid did not reach the appropriate concentration in most tissues and organs, its indication became restricted to the treatment of simple urinary tract infections (Nava, 2007). As a consequence, other quinolones have been synthesized and tested that broaden the antibacterial spectrum and the usefulness of these drugs (Silva, 2004).

The introduction of different functional groups into the quinolone structure gave rise to new compounds with a broader spectrum of action, better pharmacokinetics, lower toxicity, that were capable of outstripping the resistance of different microorganisms (Sousa, 2007).

Although many fluoroquinolones have been synthesized, the most known and used among this group are amilofloxacin, ciprofloxacin, danofoxacin, enrofloxacin, marbofloxacin, norfloxacin and sarafloxacin (Otero et al., 2001a). 


\section{METABOLISM AND EXCRETION}

Fluoroquinolones are eliminated from the body primarily by hepatic metabolism and renal excretion. In general, fluoroquinolones are partially metabolized in the liver and excreted in bile and urine containing high active drug concentration (unchanged drug or active metabolite) (Otero et al., 2001b). Ciprofloxacin, for example, is $65 \%$ excreted in urine and only $25 \%$ in the feces (Krause, 2009).

\section{APPLICATION OF FLUOROQUINOLONES}

Currently, quinolones are one of the major classes of antimicrobials and are therefore used worldwide in the treatment of infections of bacterial origin and in therapeutic indications ranging from application in urinary tract infections to virtually the whole body (Otero et al., 2001a) and are very important in the treatment against gram negative and gram positive organisms. The latest generations of these antimicrobials are active against anaerobic bacteria, including those resistant to $\beta$-lactam antibiotics and sulfonamides, making these drugs useful in therapy for a wide range of infections (Silva, 2004). Quinolone's therapeutic action is crucial, especially in infections caused by organisms resistant to other classes of drugs (Sousa, 2007).

In human medicine, ciprofloxacin and ofloxacin are among the most widely used quinolones in hospitals (Kümmerer et al., 2000). They are used in the treatment of sexually transmitted diseases, bone and joint infections, typhoid fever, tuberculosis, among others (Rocha et al., 2011). The more recent fluoroquinolones, such as gatilofloxacin, moxifloxacin and gemifloxacin, are employed in the treatment of acute sinusitis, chronic bronchitis, infections of the skin and soft tissues, cystitis, pyelonephritis, complicated urinary infections and gonorrhea (Lopes, 2004).

Besides their antibacterial activity, studies have found that fluoroquinolones inhibit the enzyme mammalian topoisomerase II, and are therefore used in the development of anticancer and anti HIV drugs (Rocha et al., 2011).

\section{CONSUMPTION OF ANTIBIOTICS}

Because international data are based only on estimates, the true volume of antimicrobial use in the agri-food sector is not known. Estimates of the amounts of antimicrobials used are conflicting (Bila, Dezotti, 2003; Tambosi, 2008; Kümmerer, 2009a).
Antibiotic consumption worldwide in 2003 was estimated to lie between 100,000 and 200,000 tons per year (Tambosi, 2008). In 1996, about 10,200 tons of antibiotics were used in the European Union, of which around $50 \%$ was applied in veterinary medicine and as growth promoters. In 1999, a total of 13,216 tons of antibiotics were used in the European Union and Switzerland, 65\% of which was applied in human medicine. In the United States, one estimate is that $50 \%$ of the 22,700 tons of all antimicrobials prescribed annually are for humans and $50 \%$ for use in animals, agriculture and aquaculture. A more recent report estimated that livestock producers in the United States use approximately 11,200 tons of antimicrobials for non-therapeutic purposes primarily to promote the growth of cattle, hogs, and poultry. Clinical uses are estimated at about $10 \%$ of total antimicrobial use (Kümmerer, 2009a; Sukul, Spiteller, 2007).

Considering the United States, European Union, Japan and South Korea, quinolone production and usage is around 50 tons in the form of proprietary products and 70 tons as generic quinolones; 1998 estimates of annual quinolone consumption for humans and animals in China were about 1,350 and 470 tons, respectively (Sukul, Spiteller, 2007).

\section{ENVIRONMENTAL OCCURRENCE}

Until recently, pharmaceutical compounds in the environment have drawn very little attention. Although their presence in the effluents of WWTPs had been reported, it was believed these compounds were easily biodegradable in the environment as most could be metabolized and transformed to some extent in humans (Kümmerer et al., 2000; Ikehata et al., 2006). However, a large number of recent studies have demonstrated the persistence of these pharmaceuticals in the aquatic environment (Ikehata et al., 2006).

Scientific interest in the issue of "pharmaceuticals in the environment" was awakened in the 1970s. The main information gleaned from this period was that these substances have low biodegradability. During the 1980s, the spotlight of environmental science turned away to focus on a series of other compounds, leaving the drugs somewhat forgotten. Since the mid-90s however, research on this topic has risen again, along with discussions involving chemicals which act as endocrine disruptors. Subsequently, the occurrence, effects and risks of these species in the environment have been investigated (Vasconcelos, 2006).

Studies show that pharmaceuticals and their metabolites are present in aquatic environments in many parts of the world including Germany, Brazil, Canada, 


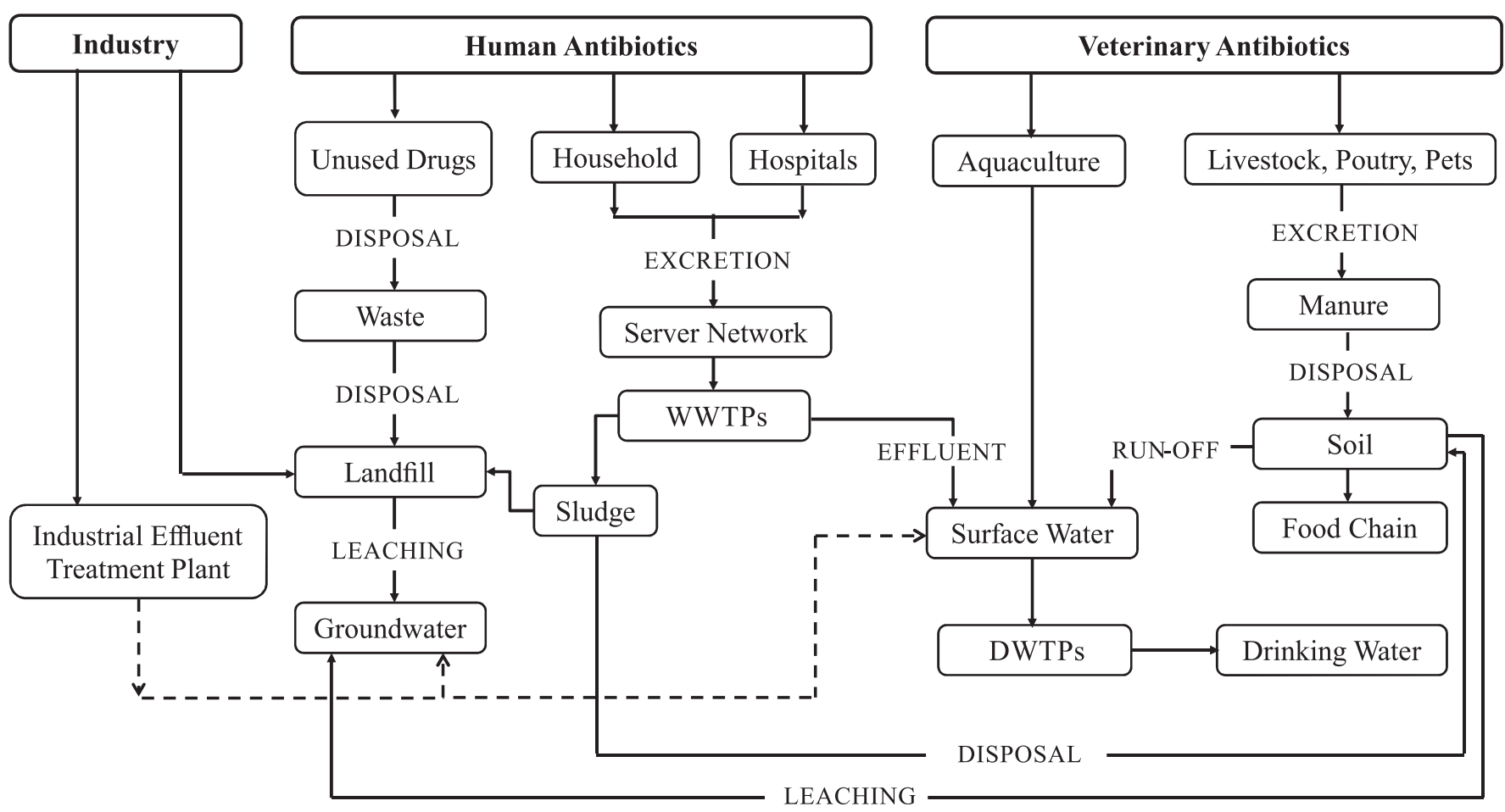

FIGURE 1 - Possible routes of antibiotics into the environment (Adapted from Bila, Dezotti, 2003; Ikehata et al., 2006; Homem, Santos, 2011).

Holland, England, Italy, Sweden, the United States, the United Kingdom (Bila, Dezotti, 2003; Ikehata et al., 2006; Tambosi, 2008), Spain (Gros et al., 2010), France, Switzerland, Greece (Melo et al., 2009), Japan (Gosh et al., 2009), Austria (Regitano, Leal, 2010), and China (Guinea et al., 2009a).

In the environment, there are three possible fates for any given drug: (1) it may be biodegradable, and therefore become mineralized into carbon dioxide and water; (2) it may undergo particular metabolic processes or be partially degraded; or (3) it may be persistent (Bila, Dezotti, 2003).

Figure 1 shows possible pathways for antibiotics, after being discarded into the environment (Bila, Dezotti, 2003):

Because of the extensive usage of fluoroquinolones, the presence and accumulation of fluoroquinolone antibacterial agents in aquatic environments have been widely reported; for example 249-405 $\mathrm{ng} \mathrm{L}^{-1}$ of ciprofloxacin and 45-120 $\mathrm{ng} \mathrm{L}^{-1}$ of norfloxacin were detected in domestic sewage in Switzerland (Golet et al., 2002; Fink et al., 2012). Higher concentrations of some fluoroquinolones $\left(0.6-2 \mu \mathrm{g} \mathrm{L}^{-1}\right)$ were also detected in wastewaters in the United States. Median concentrations of $0.02 \mu \mathrm{g} \mathrm{L}^{-1}$ and $0.12 \mu \mathrm{g} \mathrm{L}{ }^{-1}$ were reported for ciprofloxacin and norfloxacin, respectively, for samples from 139 surface streams across the United States. Additionally, ciprofloxacin in the range $0.7-124.5 \mu \mathrm{g} \mathrm{L}^{-1}$ was found in wastewater of a Swiss hospital (Fink et al., 2012).

Ciprofloxacin and norfloxacin were detected in sewage and at WWTPs in Switzerland in the range 45-568 $\mathrm{ng} \mathrm{L}^{-1}$ and 36-367 ng L $\mathrm{L}^{-1}$, respectively. The removal efficiency of these drugs in WWTPs was in the range 79-87\% (Golet et al., 2002; Kümmerer et al., 2000). Table I contains data on fluoroquinolone concentrations in the environment worldwide.

\section{WWTP sludge and sediments}

Due to the presence of several ionizable groups and the ability to form cationic, anionic or zwitterionic species, fluoroquinolones have a high tendency for sorption in soils and sediments, but this does not mean the compounds lose their antimicrobial activity (Pereira et al., 2012). Sorption is influenced by the properties of the soil, such as $\mathrm{pH}$, organic carbon content, metal oxide content, ionic strength and cation-cation exchange capacity (Aga, 2008).

The main route for degradation of veterinary antibiotics in soils is via aerobic biodegradation. Degradation rates in soil vary, with half-lives ranging from days to years. Of the quinolones, olaquindox can be considered only slightly persistent (half-life 6 to 9 days), while danofloxacin is very persistent (half-life 87 to 143 days) (Aga, 2008). 
TABLE I - Environmental concentrations of fluoroquinolones (Vasconcelos, 2006; Tambosi, 2008; Melo et al., 2009; Gosh et al., 2009; Regitano and Leal, 2010)

\begin{tabular}{|c|c|c|c|c|c|}
\hline Pharmaceutical & $\begin{array}{c}\text { Average } \\
\text { concentration } \\
\left(\mu \mathrm{g} \mathrm{L}^{-1}\right)\end{array}$ & Matrix & Pharmaceutical & $\begin{array}{c}\text { Average } \\
\text { concentration } \\
\left(\mu \mathrm{g} \mathrm{L}^{-1}\right)\end{array}$ & Matrix \\
\hline \multirow{35}{*}{ Ciprofloxacin } & 0.26 & Raw sewage/Italy & \multirow{25}{*}{ Ciprofloxacin } & \multirow{2}{*}{$3.6-101$} & Hospital effluent/ \\
\hline & 0.097 & WWTP effluent/Italy & & & Sweden \\
\hline & \multirow{2}{*}{0.06} & WWTP effluent/ & & $0.1-0.16$ & WWTP effluent/USA \\
\hline & & France & & $0.238-0.514$ & WWTP effluent/Italy \\
\hline & 0.07 & $\begin{array}{l}\text { WWTP effluent/ } \\
\text { Greece }\end{array}$ & & 0.36 & $\begin{array}{l}\text { WWTP effluent/ } \\
\text { Netherlands }\end{array}$ \\
\hline & 0.03 & $\begin{array}{l}\text { WWTP effluent/ } \\
\text { Sweden }\end{array}$ & & 0.6 & $\begin{array}{l}\text { WWTP effluent/ } \\
\text { France }\end{array}$ \\
\hline & 0.037 & $\begin{array}{l}\text { WWTP effluent/ } \\
\text { Switzerland }\end{array}$ & & 0.7 & $\begin{array}{l}\text { WWTP effluent/ } \\
\text { Greece }\end{array}$ \\
\hline & 0.02 & Surface water/USA & & 0.057 & WWTP effluent/Italy \\
\hline & 0.28 & Chicken manure/UK & & 003 & WWTP effluent/ \\
\hline & $0510^{-3}$ & Surface water/ & & 0.05 & Sweden \\
\hline & 0.5 .10 & Germany & & 15 & Hospital effluent/ \\
\hline & 387 & Hospital effluent/ & & & Sweden \\
\hline & $3-01$ & Switzerland & & 0.5 & Hospital effluent/ \\
\hline & & Hospital effluent/ & & & Sweden \\
\hline & 14.5 & Switzerland & & 151400 & Sediment hospital \\
\hline & $07-1245$ & Hospital effluent/ & & 101,700 & effluent/Sweden \\
\hline & & Switzerland & & $0.158 / 0.018$ & Before/after WWTP/ \\
\hline & 23 & Hospital effluent/ & & & Sweden \\
\hline & 2.0 & Germany & & 2540 & WWTP sludge/ \\
\hline & 06 & WWTP effluent/ & & 2,040 & Sweden \\
\hline & 0.0 & Germany & & $0.22 / 0.048$ & Before/after WWTP/ \\
\hline & 006 & Surface water/ & & & Sweden \\
\hline & 0.00 & Germany & & 31.200 & WWTP sludge/ \\
\hline & $0.055-0.405$ & WWTP effluent/ & & & Sweden \\
\hline & $0.053-0.405$ & Switzerland & & 6.3 & Surface water/Europe \\
\hline & $0.434 / 0.072$ & $\begin{array}{l}\text { Before/after WWTP/ } \\
\text { Switzerland }\end{array}$ & & 0.460 & $\begin{array}{l}\text { WWTP influent/ } \\
\text { China }\end{array}$ \\
\hline & $0.005-0.018$ & Surface water/ & Norfloxacin & $0.085-0.320$ & WWTP effluent/China \\
\hline & & Sy & & $0.155-0.486$ & WWTP influent/Japan \\
\hline & $270-2.420$ & Sludge/Switzerland & & & Chicken manure/ \\
\hline & $0.02-0.03$ & Surface water/USA & Enrofloxacin & 2,800 & Austria \\
\hline & $0.427 / 0.071$ & Before/after WWTP/ & & $0.007-0.085$ & WWTP influent/Japan \\
\hline & & Swizerrand & I syofloygcin & $0.255-0.587$ & WWTP influent/Japan \\
\hline & 5,300 & $\begin{array}{l}\text { Activated sludge/ } \\
\text { Switzerland }\end{array}$ & Levonoxacin & 0.981 & WWTP influent/Japan \\
\hline & 0.118 & WWTP effluent/ & $\underline{\text { Nalidixic acid }}$ & 0.007-0.040 & WWTP influent/Japan \\
\hline & $0.118-1-1>-1$ & Canada & Ofloxacin & $0.110-1$ & WWTP effluent/ USA \\
\hline
\end{tabular}




\section{Uptake by plants}

Some veterinary antibiotics have the ability to transfer from soil to plants. Measurable antibiotic residues are present in soil for some months after the application of manure containing these compounds. Some of these drugs are taken up by vegetables, such as carrot roots (tubers), lettuce leaves, green onions, cabbages, cucumbers, potatoes and corn. The exposure route may, however, be important when veterinary antibiotics have very low acceptable daily intake values, when they may cause subtle effects over prolonged periods, or when exposure occurs via several routes at once (Kümmerer, 2009a; Homem, Santos, 2011).

Studies have shown that concentrations of enrofloxacin of over $100 \mu \mathrm{g} \mathrm{L} \mathrm{L}^{-1}$ presented toxicity in roots, cotyledons and leaves of several cultivated plant species, such as beans, cucumbers, lettuce and radish; plants were able to convert part of the enrofloxacin absorbed into the enrofloxacin metabolite, ciprofloxacin (Regitano, Leal, 2010).

\section{ECOTOXICITY}

Ecotoxicological data in the open literature are available for less than $1 \%$ of the drugs, and only a small number of these few compounds have been subjected to risk assessment using ecotoxicological tests. Pharmaceuticals are designed to act on specific organs, tissues, cells or biomolecules, or on specific metabolic and molecular pathways in human and animals, but also have relevant side effects. Drugs introduced into the environment can affect animals through the same pathways and act on similar functions to those affected in humans. For many drugs, the specific effects or modes of action are not well known and often, not only one, but several different modes of action can occur (Tambosi, 2008).

Test systems are used to assess the interaction of antibiotics and bacteria in the environment. However, when several compounds with different activity spectra are tested, microbial population dynamics of a population may conceal effects on other populations, masking the results. In addition, environmental parameters, such as $\mathrm{pH}$, temperature, nutrients and light, may be different from those tested, as may the quantity and quality of bacteria and other microorganisms present (Kümmerer, 2009b).

Toxicity tests are usually conducted at concentrations above $1 \mu \mathrm{g} \mathrm{L}^{-1}$, to assess acute toxicity, while in the environment, organisms are exposed continuously to low concentrations of several kinds of compounds simultaneously, and so chronic effects are most probable, besides the possibility of additive or synergic effects of this mixture of compounds (Melo et al., 2009).

According to the literature, fluoroquinolones are considered highly toxic to bacteria, toxic to algae and plants, and considered dangerous to fish and crustaceans (Vasconcelos, 2006; An et al., 2010).

A number of studies on toxicity have been conducted, some of which are described below.

Vasconcelos et al. (2009) studied the photodegradation of ciprofloxacin, identifying the primary by-products, and assessed their biodegradability and toxicity. The photo-products were obtained by irradiation with a medium-pressure mercury arc lamp. Ciprofloxacin showed no effects against Vibrio fisheri at concentrations up to $300 \mu \mathrm{g} \mathrm{L}^{-1}$. The antimicrobial activity against bacteria was still present. Thus, the total toxicity of remaining ciprofloxacin and formed photo-products had been reduced, i.e. the toxicity of the photo-products was probably no higher than that of ciprofloxacin itself (Vasconcelos et al., 2009).

Ge et al. (2010) studied the aquatic photochemistry of fluoroquinolones and the toxicity of the oxidation products as well as luminescence inhibition to Vibrio fischeri. The eight fluoroquinolones (ciprofloxacin, danofloxacin, levofloxacin, sarafloxacin, difloxacin, enrofloxacin, gatifloxacin, and balofloxacin) exhibited similar toxicities. During photodegradation, the toxicities first decreased, then increased, and finally decreased, implying the generation of some intermediates of greater toxicity than the parent compound. In natural water bodies, the levels of fluoroquinolones are usually lower than the concentrations employed in the study. Thus, the fluoroquinolone concentrations may have been too low to exhibit their photomodified toxicities (Ge et al., 2010).

Li et al. (2011) studied the photolysis of enrofloxacin in water under simulated sunlight irradiation using a Xenon lamp. The toxicity of enrofloxacin and its degradation products during the irradiation were evaluated using the Vibrio fischeri test. The results showed the generation of some intermediates that were more toxic in comparison to the parent compound, followed by the degradation of the most toxic intermediates.

During the first hour, the increased toxicity may have resulted from the degradation products. LC-MS analysis showed that some groups were detached from the quinolone moiety of enrofloxacin. These group losses resulted in a lower steric hindrance and easier penetration into the cell of luminescent bacteria, which subsequently led to the increase in toxicity. One hour later, the toxicity of the products decreased, suggesting the intermediates were degraded to some less toxic products. During irradiation, 
the mixed products first showed increasing toxicity and then decreasing toxicity to the luminescent bacteria $(\mathrm{Li}$ et al. 2011).

Yuan et al. (2011) studied the photodegradation and toxicity of the antibiotics oxytetracycline, doxycycline and ciprofloxacin in the $\mathrm{UV}$ and $\mathrm{UV} / \mathrm{H}_{2} \mathrm{O}_{2}$ process. Toxicity of the three antibiotics and their reaction samples was evaluated using Vibrio fischeri. Toxicity increased during UV photolysis when the characteristic structure of the parent compounds was preserved. In the $\mathrm{UV} / \mathrm{H}_{2} \mathrm{O}_{2}$ process, toxicity first increased and then decreased, where nontoxic products were formed by the oxidation of hydroxyl radical. An increased toxic effect occurred in UV direct photolysis with the decay of the target compounds. In the $\mathrm{UV} / \mathrm{H}_{2} \mathrm{O}_{2}$ process, the toxicity initially increased and then decreased to no measurable toxicity. Based on these results, the oxidation of the three antibiotics could be better explained if divided into two stages: the first stage, comprising the degradation of the parent compounds causing increased toxicity of by-products; and the second stage, in which the more toxic by-products were further converted into non-toxic by-products (Yuan et al., 2011).

\section{BIODEGRADABILITY}

Antibiotics generally show low biodegradability since they are biocides whose degradation cannot be accomplished in the environment or at WWTPs (Balcioglu, Ötker, 2004).

Some antibiotics found in the soil and sediments proved to be very persistent in laboratory tests as well as in field studies. Some do not biodegrade well under aerobic or anaerobic conditions (Kümmerer, 2009a).

Kümmerer et al. (2000) studied the biodegradability of some antibiotics, including ciprofloxacin and ofloxacin. None of the test compounds were biodegraded to any extent in this test system. Therefore, none of the antibiotics listed above can be classified as "readily biodegradable". In the test controls with ciprofloxacin and ofloxacin, an inhibition of biodegradation was observed within the first few days of the test. This inhibition disappeared after 8 and 11 days, respectively. Furthermore, the quinolones ciprofloxacin and ofloxacin showed high genotoxic activity. In an aquatic model ecosystem, the elimination of ciprofloxacin took place by adsorption onto the sediment, but the mineralization process was relatively slow. Sarafloxacin, a fluoroquinolone registered for use against poultry diseases, was mineralized by less than $1 \%$ in various soils within 80 days, probably because of its strong binding to soil. Ciprofloxacin was not biodegradable in a closed bottle test. In general, only low degradation rates may occur in surface waters and sediments (Kümmerer et al., 2000).

Vasconcelos et al. (2009) studied the biodegradability of primary by-products generated by photolysis of ciprofloxacin. The initial concentration of the antibiotic was $100 \mu \mathrm{g} \mathrm{L}^{-1}$, a level similar to that found in wastewaters of the Hospital of the University of Santa Maria, Brazil. The samples were submitted to the closed bottle test in order to obtain biodegradability information about the by-products formed during the photo-process. The irradiated samples exhibited no difference in comparison to those prior to treatment, showing that the photo-process did not increase the biodegradability or toxicity against the bacteria present. The presence of a secondary carbon source may sometimes improve biodegradability. However, a test showed that the photo-products formed were not biodegradable even in the presence of a secondary readily biodegradable carbon source (Vasconcelos et al., 2009).

\section{ACTION INVOLVING MICROORGANISMS, PLANTS, BIOACCUMULATION, AND NATU- RAL DEGRADATION}

Pharmaceuticals which persist after treatment at WWTPs may affect organisms of different trophic levels. For example, in a model aquatic system using synthetic fresh water, nitrifying bacteria were affected by an aquaculture antibiotic (Kümmerer, 2009a).

Bacteria, fungi and microalgae are the organisms primarily affected by antibiotics, because antibiotics are designed to affect microorganisms. In general, the effects of antibiotics on bacteria and microalgae are found to be 2 to 3 orders of magnitude below the toxic values for higher trophic levels (Kümmerer, 2009a).

The sensitivity of algae to antibiotics varies widely. Blue-green algae (cyanobacteria) for example, have demonstrated sensitivity to many antibiotics, such as sarafloxacin. Algae are affected by antibiotics, which in turn may affect the balance in aquatic systems, since algae are the base of the food chain (Kümmerer, 2009a).

Common receptors have been identified in plants for a number of antibiotics affecting chloroplast replication (fluoroquinolones), transcription and translation (tetracyclines macrolides, lincosamides, P-aminoglycosides, and pleuromutilins), metabolic pathways such as folate biosynthesis (sulphonamides) and fatty acid biosynthesis (triclosan) (Kümmerer, 2009a).

Exposure to antibiotics in the environment may have adverse reproductive effects in the early life stages of different organisms. A significantly depressed hatching rate for Artemia sp. cysts and a high mortality rate for 
nauplii as well as toxic effects on reproduction of Daphnia magna demonstrate how serious the impacts of antibiotics on these organisms can be. The capability of altering the pigmentation of Artemia salina nauplii, thus resulting in a loss of fitness for these individuals was demonstrated for the antibiotic flumequine.

Antibiotics in the environment can also affect the behavior of aquatic organisms.

For instance, it has been shown that antibiotics can influence the phototaxis (locomotory movement) of Daphnia magna (Kümmerer, 2009a).

Robinson et al. (2005) performed toxicity tests with seven fluoroquinolone antibiotics (ciprofloxacin, lomefloxacin, ofloxacin, levofloxacin, clinafloxacin, enrofloxacin) and flumequine, on five aquatic organisms. Overall toxicity values ranged from 7.9 to $23,000 \mu \mathrm{g} \mathrm{L}^{-1}$. The cyanobacterium Microcystis aeruginosa was the most sensitive organism, followed by duckweed, and the green alga Pseudokirchneriella sub-capitata. Results from tests with the crustacean Daphnia magna (48 h survival) and fathead minnow (Pimephales promelas, 7-day early life stage survival and growth) showed limited toxicity with no-observed-effect concentrations at or near $10 \mathrm{mg} \mathrm{L}^{-1}$. At an estimated environmental concentration of $1 \mu \mathrm{g} \mathrm{L}^{-1}$ only M. aeruginosa may be at risk in surface water (Robinson et al., 2005).

\section{PHYSICAL, CHEMICAL AND BIOLOGICAL TREATMENTS}

During the last century, many different technologies were developed to remove pollutants from urban wastewaters, where they can be present at high concentrations of the order of $\mu \mathrm{g} \mathrm{L}^{-1}$ to $\mathrm{mg} \mathrm{L}^{-1}$.

Most conventional wastewater and drinking water treatments are based on biological degradation, coagulation, flocculation, sedimentation and filtration processes shown to be inefficient for removing/destroying pharmaceuticals including antibiotics. Therefore, enhancing the development of new and more efficient processes is necessary (Balcioglu, Ötker, 2004; Homem, Santos, 2011).

High degradation efficiencies of organic contaminants, including fluoroquinolones are obtained by AOPs, which can be defined as aqueous phase oxidation methods based on highly reactive oxygen species, such as hydroxyl radicals (Fink et al., 2012). Advanced oxidation and reduction processes typically involve the formation of hydroxyl radicals $\left({ }^{\circ} \mathrm{OH}\right)$ as oxidizing species and either hydrated electrons $\left(\mathrm{e}_{\mathrm{aa}}^{-}\right)$or hydrogen atoms $\left(\mathrm{H}^{*}\right)$ as reducing species, all of which can be used in the destruction of organic pollutants present in drinking and wastewater (Santoke et al., 2009).

AOPs are characterized by a variety of radical reactions that involve combinations of chemical agents (e.g., $\mathrm{O}_{3}$, hydrogen peroxide, transition metals, and metal oxides) and auxiliary energy sources (e.g., UV-VIS radiation, electric current, $\gamma$-radiation and ultrasound). Examples of AOPs include $\mathrm{H}_{2} \mathrm{O}_{2} / \mathrm{UV}$, Fenton $\left(\mathrm{Fe}^{2+} /\right.$ $\mathrm{H}_{2} \mathrm{O}_{2}$ ), photo- and electro-Fenton, chelating agent-assisted Fenton/photo-Fenton, heterogeneous photo oxidation using titanium dioxide $\left(\mathrm{TiO}_{2}\right), \gamma$-radiolysis, and sonolysis (Petrovic et al., 2011). When the oxidation agent is sufficiently powerful, such as hydroxyl radicals, a complete mineralization of pollutants to carbon dioxide, water, and inorganic compounds is possible, or at least a conversion of the organic pollutants into highly oxidized products which are often susceptible to further degradation.

Hydrogen peroxide is a commonly used auxiliary oxidation agent, with reduction potential varying with $\mathrm{pH}$. It is not sufficiently strong to oxidize most organic pollutants by itself and is therefore often used in combination with other reagents, catalysts, or UV irradiation which together induce the formation of hydroxyl radicals (Fink et al., 2012).

Manganese oxides, commonly found in soils and sediments, are among the most important natural reactants or catalysts in facilitating organic pollutant transformation. On the basis of the strong affinity of fluoroquinolones for soils and sediments, there is great potential for fluoroquinolones to react with mineral components in such systems (Zhang, Huang, 2005).

Previous studies have reported rapid reactions of ciprofloxacin and enrofloxacin with chlorine dioxide $\left(\mathrm{ClO}_{2}\right)$ and ozone. Chlorine dioxide is a powerful disinfectant that has comparable biocidal efficacy, but less $\mathrm{pH}$ dependence and disinfection by-product formation potential compared to free chlorine, and is a highly selective oxidant. The structures of fluoroquinolone molecules contain both aliphatic and aromatic amine moieties and thus are likely to be susceptible to oxidation by $\mathrm{ClO}_{2}$ (Wang et al., 2010).

Heterogeneous catalysis by semiconductors has been proven to be highly efficient in organic pollutant degradation. It involves the exposure of the semiconductors (usually metal oxides) as particles suspended in aqueous solutions of the pollutant or as thin films. Among its advantages, heterogeneous catalysis offers rapid removal of contaminants, less or no polycyclic by-products, and degradation of pollutants in the $\mu \mathrm{g} \mathrm{L}^{-1}$ range. The most common heterogeneous catalyst is titanium dioxide combined with UV irradiation at 300-400 $\mathrm{nm}$. In this 
method, the semiconductor acts as a sensitizer for lightinduced redox processes. Other semi-conductors such us $\mathrm{ZnO}, \mathrm{ZnS}, \mathrm{Fe}_{3} \mathrm{O}_{4}, \mathrm{Fe}_{2} \mathrm{O}_{3}$, and $\mathrm{CuO}$, have also been found to be effective (Fink et al., 2012).

$\mathrm{UV} / \mathrm{H}_{2} \mathrm{O}_{2}$ has been proposed as an effective treatment method for organic contaminants in drinking water and reclaimed water. In this process, pollutants are degraded in two ways. Some organic chemicals absorb UV light directly, causing destruction of chemical bonds and subsequent breakdown of the contaminant. However, other organic species do not degrade quickly or efficiently by direct UV photolysis. Therefore, the addition of $\mathrm{H}_{2} \mathrm{O}_{2}$ is necessary to degrade contaminants more efficiently. However, the presence of hydroxyl radical scavengers in natural water matrices, including carbonate species $\left(\mathrm{HCO}_{3}^{-}, \mathrm{CO}_{3}{ }^{2-}\right)$, natural organic matter and other organic compounds, could have a negative influence on the efficiency of $\mathrm{UV} / \mathrm{H}_{2} \mathrm{O}_{2}$. Mineralization of trace organic compounds is a preferred goal when treating wastewater effluents for water reuse applications or drinking water from wastewater-impacted sources. However, during these wastewater treatments, complete mineralization is often unfeasible (Yuan et al., 2011).

Photolysis is one of the most important ways of attaining antibiotic elimination in natural aquatic environments. In natural waters, humic substances and nitrate ions may contribute to the degradation of residual drugs, since under exposure to sunlight they are able to generate highly reactive species, such as singlet oxygen and hydroxyl radicals. On the other hand, humic substances absorb a broad range of radiation, thus reducing the amount of free energy for other organic molecules acting as a filter and thus preventing direct photolysis (Melo et al., 2009).

Recently, several studies have been conducted to determine the most effective process and the most favorable conditions for the degradation of fluoroquinolones. Some of these studies are listed below.

Wetzstein et al. (1997) studied the degradation of enrofloxacin with the brown rot fungus Gloeophyllum striatum. Enrofloxacin at $10 \mathrm{mg} \mathrm{L}^{-1}$ was transformed into metabolites after only 1 week. The metabolites formed suggested the existence of four main degradation routes that may occur simultaneously. Each route, initiated by either oxidative decarboxylation, defluorination, hydroxylation at C-8, or oxidation of the piperazinyl moiety, may reflect an initial attack by hydroxyl radicals at a different site of the drug. During chemical degradation of enrofloxacin with Fenton's reagent, five metabolites were identified. These findings provide new evidence to support the hypothesis that brown rot fungi may be capable of producing hydroxyl radicals, which could be used to degrade wood and certain xenobiotics (Wetzstein et al., 1997).

Wetzstein et al. (1999) studied the degradation of ciprofloxacin by basidiomycetes and the identification of metabolites generated by brown rot fungus Gloephyllum striatum. Its degradation by basidiomycetous fungi was studied by monitoring $\mathrm{CO}_{2}$ production from ciprofloxacin in liquid cultures. Sixteen species present in wood, soil, humus, or animal dung produced up to $35 \% \mathrm{CO}_{2}$ during 8 weeks of incubation. Despite some low rates of $\mathrm{CO}_{2}$ formation, all species tested had reduced the antibacterial activity of ciprofloxacin in supernatants to between 0 and $33 \%$ after 13 weeks. Gloeophyllum striatum was used to identify the metabolites formed from ciprofloxacin. After 8 weeks, mycelia had produced 17 and $10 \% \mathrm{CO}_{2}$ from $\mathrm{C}-4$ and the piperazinyl moiety, respectively, although more than half of ciprofloxacin (applied at $10 \mathrm{ppm}$ ) had been transformed into metabolites after $90 \mathrm{~h}$. For the first time, these findings revealed the widespread potential for ciprofloxacin degradation among basidiomycetes dispersed in various environments, including agricultural soils and animal dung (Wetzstein et al., 1999).

Balcioglu and Ötker (2004) studied the treatment of a simulated enrofloxacin production wastewater with $\mathrm{O}_{3}$, $\mathrm{O}_{3} / \mathrm{H}_{2} \mathrm{O}_{2}$ and $\mathrm{O}_{3} / \mathrm{UV}$ processes, and the efficiencies of the treatment processes were compared by means of chemical oxygen demand (COD), absorbance removals, and biodegradability enhancement. The results indicated that for the treatment by ozonation, $\mathrm{pH}$ control is an important factor in order to obtain high efficiency treatment. By using ozonation at $\mathrm{pH}=12$, the $\mathrm{BOD}_{5} / \mathrm{COD}$ ratio was improved to 0.5 . The introduction of $\mathrm{H}_{2} \mathrm{O}_{2}$ did not enhance the treatment efficiency of the simulated wastewater. With the $\mathrm{O}_{3} / \mathrm{UV}$ process, the contribution of UV light to the overall destruction of benzene rings and biodegradability enhancement was high. Consequently, ozonation and photolytic ozonation processes seem to be promising methods for the pretreatment of antibiotic formulationcontaining wastewaters (Balcioglu, Ötker, 2004).

Zhang and Huang (2005) studied the oxidative transformation of fluoroquinolone and structurally related amines by manganese oxide. In the study, high reaction rates of fluoroquinolones with manganese oxides were obtained. Seven fluoroquinolones (ciprofloxacin, enrofloxacin, norfloxacin, ofloxacin, lomefloxacin, pipemidic acid and flumequine) were examined for adsorptive and oxidative interactions with $\mathrm{MnO}_{2}$ under environmental conditions. No detectable antimicrobial activity was observed for the photodegradation products of ciprofloxacin; in contrast, antimicrobial activity against Escherichia coli, Enterobacter cloacae, and Klebsiella 
oxytoca was statistically significant even after increased levels of photodegradation for ofloxacin and levofloxacin. Dealkylated products have much lower antimicrobial activity than the defluorinated products. If the above reasoning is indeed correct, the dealkylated oxidation products of fluoroquinolones with manganese oxide would mean reduction in antimicrobial activity. This study strongly suggested that manganese oxides commonly present in soils will likely play an important role in the abiotic degradation of fluoroquinolones in the environment (Zhang, Huang, 2005).

Zhang and Huang (2007) studied the adsorption and oxidation of seven fluoroquinolones (ciprofloxacin, enrofloxacin, norfloxacin, ofloxacin, lomefloxacin, pipemidic acid and flumequine) and structurally related amines with goethite. This study demonstrated that interactions of fluoroquinolones with Fe oxide were very strong over a wide range of environmental conditions, and involved both adsorption and oxidation. Adsorption of fluoroquinolones onto goethite is strong and fast, whereas oxidation continues slowly yielding a range of by-products. The carboxylic group of fluoroquinolone is critical for adsorption while the piperazinyl ring is susceptible to oxidation; both functional groups are present in most members of fluoroquinolones. In comparison to the work of Zhang and Huang (2005) on the interactions of fluoroquinolones with Mn oxide, fluoroquinolones have different adsorption sites (piperazine ring versus carboxylic group, respectively) but the same oxidation site (the piperazine ring) toward $\mathrm{Mn}$ and iron oxides. Although different adsorption behavior is involved with these two oxides, the same radical-based oxidation mechanism is present in both cases. Results of this study indicated that Fe oxides in aquatic sediments may play an important role in the natural degradation of fluoroquinolones (Zhang, Huang, 2007).

Guinea et al. (2009a) studied simulated wastewater containing enrofloxacin using electrochemical oxidation by a diamond conductor, ozonation and the Fenton process. The use of electrochemical oxidation by a diamond conductor is the most efficient technology concerning mineralization. This indicates that ozonation is more efficient for destroying complex organic molecules, but not for removing carboxylic acids. The high efficiency of initial oxidation by the Fenton process shows that this process is very efficient in the removal of enrofloxacin, despite slight rapidly forming refractory compounds. This indicates the significance of other oxidation mechanisms that improve the results.

Santoke et al. (2009) studied the oxidative and reductive degradation of six fluoroquinolones, orbifloxacin, flumequine, marbofloxacin, danofloxacin, enrofloxacin, and a model compound (6-fluoro-4-oxo1,4-dihydro-3-quinololine carboxylic acid) through electron pulse radiolysis, which generate hydroxyl radicals, and gamma radiolysis, which generates hydrated electrons. The most degraded compound by hydroxyl radicals was marbofloxacin, followed by flumequine, enrofloxacin, the model compound, orbifloxacin and danofloxacin. The most degraded compound by hydrated electrons was marbofloxacin, followed by orbifloxacin, enrofloxacin, flumequine, danofloxacin and the model compound. The major degradation mechanisms arising from gamma irradiation of fluoroquinolone antibiotics appear to involve hydroxyl radical addition to the aromatic ring to form mixtures of phenolic compounds. Hydroxyl radicals can replace hydrogen atoms, fluorine atoms, or entire substituted piperazine rings (Santoke et al., 2009).

An et al. (2010) studied the advanced oxidation treatment of three fluoroquinolones (norfloxacin, levofloxacin and lomefloxacin) using $\mathrm{TiO}_{2}$ heterogeneous catalysis. The rate of destruction was shown to be similar for all three compounds. The photocatalytic degradation mechanisms proposed for three fluoroquinolones and three mechanisms, were also shown to be similar for all three compounds. The loss of fluoride ions suggested that the compounds will be more susceptible to biodegradation if mineralization is not achieved. However, most of the intermediates produced can be mineralized into $\mathrm{CO}_{2}$, water, and mineral species within 180 minutes by the photocatalytic degradation process (An et al., 2010).

Ge et al. (2010) studied the aquatic photochemistry of fluoroquinolone antibiotics. In this study, eight fluoroquinolones (ciprofloxacin, danofloxacin, levofloxacin, sarafloxacin, difloxacin, enrofloxacin, gatifloxacin, and balofloxacin) were exposed to simulated sunlight. The result of solar photodegradation in pure water suggested that fluoroquinolones would intrinsically photodegrade fast in sunlight surface waters. However, the authors found that freshwater and seawater constituents, such as humic acids (HA), $\mathrm{Fe}(\mathrm{III}), \mathrm{NO}_{3}^{-}$,

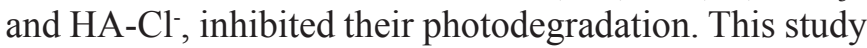
found that exposure to sunlight facilitated the decay of fluoroquinolones in the euphotic zone of surface waters. However, the photolytic mechanisms and the multivariate role of water constituents in fluoroquinolones photolysis need to be taken into account when assessing the fate of fluoroquinolones (Ge et al., 2010).

Sturini et al. (2010) investigated the photochemical fate of marbofloxacin and enrofloxacin, two 
fluoroquinolones largely used as bactericides and present in surface waters. The degradation of these pollutants (5-50 $\mu \mathrm{g} \mathrm{L}^{-1}$ starting concentration) was complete after 1 hour of exposure to solar light. All of the primary products were themselves degraded after 1 hour. The reaction rates were scarcely affected by $\mathrm{Ca}^{2+}\left(200 \mathrm{mg} \mathrm{L}^{-1}\right), \mathrm{Mg}^{2+}$ (30 $\left.\mathrm{m} \mathrm{L}^{-1}\right), \mathrm{Cl}^{-}\left(30 \mathrm{mg} \mathrm{L}^{-1}\right)$, and humic acid $\left(1 \mathrm{mg} \mathrm{L}^{-1}\right)$, but increased in the presence of phosphate $\left(20 \mathrm{mg} \mathrm{L}^{-1}\right)$. The fastest degradation of enrofloxacin occurred at $\mathrm{pH} 8$ where the zwitterionic form was present, while in the case of marbofloxacin the cationic form was the most reactive (Sturini et al., 2010).

Wang et al. (2010) studied the oxidation of seven fluoroquinolones (ciprofloxacin, enrofloxacin, norfloxacin, ofloxacin, lomefloxacin, pipemidic acid and flumequine) and three structurally related amines by chloride dioxide. Comparison among fluoroquinolones and related amines and product characterization indicated that piperazine rings of fluoroquinolones are the primary reactive center to $\mathrm{ClO}_{2}$. However, the transformation may not eliminate antibacterial activity because of the little destruction at the quinolone ring. Oxidation of fluoroquinolones by $\mathrm{ClO}_{2}$ leads to dealkylation, hydroxylation and intramolecular ring closure at the piperazine moiety, while leaving the quinolone ring mostly intact, which is strongly related to the antimicrobial properties of fluoroquinolones.

The decay of fluoroquinolones by $\mathrm{ClO}_{2}$ is influenced by water matrices, particularly in wastewater (Wang et al., 2010).

Li et al. (2011) studied the photolysis of enrofloxacin in water under simulated sunlight irradiation using a Xenon lamp. After irradiation for 90 minutes, only 13.1\% reduction in total organic carbon (TOC) occurred in spite of fast photolysis of $58.9 \%$ of enrofloxacin, indicating that enrofloxacin was transformed into intermediates without complete mineralization. The photolysis of enrofloxacin involved three main mechanisms: decarboxylation, defluorination, and piperazinyl $N$-dealkylation. The assay using Vibrio fischeri indicated the generation of intermediates with greater toxicity than enrofloxacin $(\mathrm{Li}$ et al., 2011).

Fink et al. (2012) investigated the chemical oxidation of enrofloxacin by hydrogen peroxide catalyzed by nanoparticles of copper oxide $(\mathrm{CuO})$, titanium carbide $(\mathrm{TiC})$ and silicon nitride $\left(\mathrm{Si}_{3} \mathrm{~N}_{4}\right)$. The reaction medium consisted of an aqueous solution of enrofloxacin $1,000 \mu \mathrm{g} \mathrm{L}^{-1}, 0.1 \mathrm{~g} \mathrm{~L}^{-1}$ of nanoparticles and $0.8 \mathrm{~mol} \mathrm{~L}^{-1}$ of hydrogen peroxide. At the reaction time of 240 minutes, 150,200 and $600 \mathrm{mg} \mathrm{L}^{-1}$ of residual enrofloxacin was obtained for $\mathrm{CuO}, \mathrm{TiC}$ and $\mathrm{Si}_{3} \mathrm{~N}_{4}$, respectively. The process catalyzed by nanoparticles was more efficient for $\mathrm{CuO}$ (Fink et al., 2012).

Sturini et al. (2012) studied the photodegradation by sunlight of marbofloxacin and enrofloxacin adsorbed in soils. Soil samples spiked with fluoroquinolones $(0.5$ $\mathrm{mg} \mathrm{kg}{ }^{-1}$ ) were exposed to solar light, promoting extensive degradation ( $80 \%$ ) of both drugs in $60-150$ hours. The photodegradation of marbofloxacin resulted in the same efficiency and mechanisms observed in aqueous solutions, and involved the cleavage of the tetrahydrooxadiazine ring. By contrast, the same treatment applied for enrofloxacin resulted in fewer photoproducts than the number determined in aqueous solutions (those arising from stepwise oxidation of the piperazine side chain). From an environmental point of view, it is important to note that photodegradation mainly affects the side-chains, while the fluoroquinolone ring, to which the biological effect is associated, remains conserved up to the later stages of degradation (Sturini et al., 2012).

\section{CONCLUSION}

Due to the high consumption of fluoroquinolones and their high affinity to soil, most of these compounds are adsorbed on sludge from WWTPs. With the common practice of using this sludge as fertilizer, fluoroquinolones may be transferred to plants, entering the human food chain. For this reason, it is necessary to develop effective treatments for the destruction or inactivation of these compounds. According to studies, the degradation of fluoroquinolones adsorbed in soil is possible; however, more than one AOP would need to be evaluated concerning the generation of degradation products that have no antimicrobial activity, in order to mitigate the tendency of the emergence of bacteria resistant to the drugs currently in use.

\section{REFERENCES}

AGA, D. S. Fate of pharmaceuticals in the environment and in water treatments systems. New York. CRC Press, Taylor \& Francis Group, 391 pages, 2008.

AN, T.; YANG, H.; SONG, W.; LI, G.; LUO, H.; COOPER, W.J. Mechanistic considerations for the advanced oxidation treatment of fluoroquinolone pharmaceutical compounds using $\mathrm{TiO}_{2}$ heterogeneous catalysis. J. Phys. Chem. A, v.114, p. 2569-2575, 2010.

BALCIOGLU, I. A.; ÖTKER. M. Pre-treatment of antibiotic formulation wastewater by $\mathrm{O}_{3}, \mathrm{O}_{3} / \mathrm{H}_{2} \mathrm{O}_{2}$, and $\mathrm{O}_{3} / \mathrm{UV}$ processes. J. Environ. Eng. Sci., v.28, p.325-331, 2004. 
BILA, D. M.; DEZOTTI, M. Fármacos no meio ambiente. Quim. Nova, v.24, n.4, p.523-530, 2003.

BILA, D. M. Degradação e remoção da atividade estrogênica do desregulador endócrino $17 \beta$-estradiol pelo processo de ozonização. Rio de Janeiro, 2005. 281 p. [Thesis of $\mathrm{PhD}$ degree. Faculty of Pharmaceutical Sciences, Federal University of Rio de Janeiro] .

FINK, L.; DROR, I.; BERKOWITZ, B. Enrofloxacin oxidative degradation facilities by metal oxide nanoparticles. Chemosphere, v.86, p.144-149, 2012.

GE, L.; CHEN, J.; WEI, X.; ZHANG, S.; QIAO, X.; CAI, $\mathrm{X}$; XIE, Q. Aquatic photochemistry of fluoroquinolone antibiotics: kinetics, pathways, and multivariate effects of main water constituents. Environ. Sci. Technol., v.44, p.2400-2405, 2010

GOLET, E. M.; ALDER, A. C.; GIGER, W. Environmental exposure and risk assessment of fluoroquinolones antibacterial agents in wastewater and river water of the Glatt Valley Watershed, Switzerland. Environ. Sci. Technol., v.36, p.3645-3651, 2002.

GOSH, G. C.; OKUDA, T.; YAMASHITA, N.; TANAKA, H. Occurrence and elimination of antibiotics at four sewage treatments plants in Japan and their effects on bacterial ammonia oxidation. Water Sci. Technol., v.59, p.79-786, 2009.

GROS, M.; PETROVIC, M.; GINEBREDA, A.; BARCELÓ, D. Removal of pharmaceuticals during wastewater treatment and environmental risk assessment using hazard indexes. Environ. Int., v.36, p.15-26, 2010.

GUINEA, E.; BRILLAS, E.; CENTELLAS, F.; CAÑIZARES, P.; RODRIGO, M. A.; SÁEZ, C. Oxidation of enrofloxacin with condutive-diamond electrochemical oxidation, ozonation and Fenton oxidation. A comparison. Water Res., v.43, p.2131-2138, 2009a.

GUINEA, E.; CENTELLAS, F.; BRILLAS, E.; CAÑIZARES, P.; SÁEZ, C.; RODRIGO, M. A. Electrocatalytic properties of diamond in the oxidation of a persistent pollutant. Appl. Catal. B-Environ., v.89, p.645-650, 2009b.

HOMEM, V.; SANTOS, L. Degradation and removal methods of antibiotics from aqueous matrices - a review. J. Environ. Manage., v.92, p.2304-2347, 2011.
IKEHATA, K.; NAGHASHKAR, N. J.; EL-DIN, M. G. Degradation of aqueous pharmaceuticals by ozonation and advanced oxidation process: a review. Ozone-Sci. Eng., v.28, p.353-414, 2006.

KLAVARIOTI, M.; MANTZAVINOS, D.; KASSINOS, D. Removal of residual pahrmaceuticals from aqueous systems by advanced oxidation process. Environ. Int., v.35, p.402417, 2009.

KRAUSE, L. G. T. Degradação do antibiótico sulfametoxazol por ozonização e avaliação da atividade antimicrobiana. Rio de Janeiro, 2009. 69 p. [Thesis of PhD degree. Faculty of Chemical Engineering, Federal University of Rio de Janeiro].

KÜMMERER，K.; AL - AHMAD, A.; MER S C H SUNDERMANN, V. Biodegradability of some antibiotics, elimination of the genotoxicity and affection of wastewater bacteria in a simple test. Chemosphere, v.40, p.701-710, 2000 .

KÜMMERER, K. Antibiotics in the aquatic environment - a review - Part I. Chemosphere, v.75, p.417-434, 2009a.

KÜMMERER, K. Antibiotics in the aquatic environment - a review - Part II. Chemosphere, v.75, p.435-441, 2009b.

LESHER, G. Y.; FROELICH, E. J.; GRUETT, M. D.; BAILEY, J. H.; BRUNDAGE, R. P. 1,8-Naphthyridine derivatives. A new class of chemotherapeutic agents. J. Med. Chem., v.5, p.1063-1065, 1962.

LI, Y.; NIU, J.; WANG, W. Photolysis of enrofloxacin in aqueous systems under simulated sunlight irradiation: kinetics, mechanism and toxicity of photolysis products. Chemosphere, v.85, p.892-897, 2011.

LIN, J-S.; PAN, H-Y.; LIU, S-M.; LAI, H-T. Effects of light and microbial activity on the degradation of two fluoroquinolone antibiotics in pound water and sediment. J. Environ. Sci. Heal. B, v.45, p.456-465, 2010.

LOPES, H. V. O papel das novas fluoroquinolonas na terapia antibiótica. Rev. Panam. Infectol, v.6, p.18-20, 2004.

MATHERS, J. J.; FLICK, S. C.; COX JR., L. A. Longer-duration uses for tetracyclines and penicillins in U.S. food-producing animals: Indications and microbiologic effects. Environ. Int., v.37, p.991-1004, 2011. 
MELO, S. A. S.; TROVÓ, A. G.; BAUTITZ, I. R.; NOGUEIRA, R. F. P. Degradação de fármacos residuais por processos oxidativos avançados. Quím. Nova, v.32, p.188-197, 2009.

NAVA, I. S. J. Determinação seletiva de fluoroquinolonas por fosforimetria na temperatura ambiente em substrato de celulose com nitrato de tório. Rio de Janeiro, 2007. 162 p. [Thesis of PhD degree. Department of Chemistry, Pontifical Catholic University of Rio de Janeiro].

Otero, J. L.; MESTORINO, N.; ERRECALDE, J. O. Enrofloxacina: una fluoroquinolona de uso exclusivo en veterinaria - Parte I: Química, mecanismo de acción, actividad antimicrobiana y resistencia bacteriana. Analecta Vet., v.21, p.31-41, 2001a.

OTERO, J. L.; MESTORINO, N.; ERRECALDE, J. O. Enrofloxacina: una fluoroquinolona de uso exclusivo en veterinaria-Parte II: Farmacocinética y toxicidad. Analecta Vet., v.21, p.42-49, 2001 b.

PENA, A.; CHMiELOVA, D.; LiNO, C. M.; SOLICH, P. Determination of fluoroquinolone antibiotics in surface from Mondego River by high performance liquid chromatography using a monolithic column. J. Sep. Sci., v.30, p.2924-2928, 2007.

PEREIRA, L. A.; JARDIM, I. C. S. F.; FOSTIER, A. H.; RATH, S. Ocorrência, comportamento e impactos ambientais provocados pela presença de antimicrobianos veterinários em solos. Quím. Nova, v.35, p.159-169, 2012.

PETROVIC, M.; RADJENOVIC, J.; BARCELO, D. Advanced oxidation process (AOPs) applied for wastewater and drinking water treatment. Elimination of pharmaceuticals. Holistic Approach to Environment 1, v.2, p.63-74, 2011.

REGITANO, J. B.; LEAL, R. M. P. Comportamento e impacto de antibióticos usados na produção animal brasileira. Rev. Bras. Cienc. Solo, v.34, p.601-616, 2010.

ROBINSON, A. A.; BELDEN, J. B.; LYDY, M. J. Toxicity of fluoroquinolone antibiotics to aquatic organisms. Environ. Toxicol. Chem., v.24, p.423-430, 2005.

ROCHA, D. P.; PINTO, G. F.; RUGGIERO, R.; OLIVERIA, C. A.; GUERRA, W.; FONTES, A. P. S.; TAVARES, T. T.; MARZANO, I. M.; PEREIRA-MAIA, E. C. Coordenação de metais a antibióticos como uma estratégia de combate à resistência bacteriana. Quím. Nova, v.34, p.111-118, 2011.
SANTOKE, H.; SONG, W.; COOPER, W. J.; GREAVES, J.; MILLER, G. E. Free-radical-induced oxidative and reductive degradation of fluoroquinolones pharmaceutical: kinetic studies and degradation mechanism. J. Phys. Chem.US, v.113, p.7846-7851, 2009.

SILVA, R. G. Farmacocinética e determinação de resíduos de enrofloxacina e seu metabólito em tecidos de frangos. Campinas, 2004. 127 p. [Thesis of PhD degree. Department of Analytical Chemistry, Institute of Chemistry, State University of Campinas].

SOUSA, I. C. S. C. Inteiração da enrofloxacina com modelos biomembranares: Influencia das suas propriedades físico químicas. Porto 2007. 107 p. [Thesis of PhD degree. Department of Chemistry, Faculty of Sciences, University of Porto].

STURINI, M.; SPELTINI, A.; MARASCHI, F.; PROFUMO, A., PRETALI, L.; FASANI, E.; ALBINI, A. Photochemical degradation of marbofloxacin and enrofloxacin in natural waters. Environ. Sci. Technol., v.44, p.4564-4569, 2010.

STURINI, M.; SPELTINI, A.; MARASCHI, F.; PROFUMO, A.; PRETALI, L.; FASANI, E.; ALBINI, A. Sunlight-induced degradation of soil-adsorbed veterinary antimicrobials marbofloxacin and enrofloxacin. Chemosphere, v.86, p.130137, 2012.

SUKUL, P.; SPITELLER, M. Fluoroquinolones antibiotics in the environment. Rev. Environ. Contam. T, v.191, p.131$154,2007$.

TAMBOSI, J. L. Remoção de fármacos e avaliação de seus produtos de degradação através de tecnologias avançadas de tratamento. Florianópolis, 2008. 141 p. [Thesis of PhD degree. Department of Chemical and Food Engineering, Federal University of Santa Catarina].

VASCONCELOS, T. G. Antimicrobial ciprofloxacina em efluente hospitalar: exposição ambiental, avaliação de risco e degradação através de processos avançados de oxidação. Santa Maria, 2006. 70 p. [Thesis of PhD degree. Faculty of Natural and Exact Sciences, Federal University of Santa Maria].

VASCONCELOS, T. G.; HENRIQUES, D. M.; KÖNIG, A.; MARTINS, A. F.; KUMMERER, K. Photo-degradation of the antimicrobial ciprofloxacin at high $\mathrm{pH}$ : identification and biodegradability assessment of the primary byproducts. Chemosphere, v.76, p.487-493, 2009. 
WANG, P.; HE, Y-L.; HAUNG, C-H. Oxidation of fluoroquinolones antibiotics and structurally related amines by chlorine dioxide: reaction kinetics, product and pathway evaluation. Water Res., v.44, p.5989-5598, 2010.

WETZSTEIN, H. G.; SHEMMER, N.; KARL, W. Degradation of the fluoroquinolone enrofloxacin by the brown rot fungus Gloephyllum striatum: identification of metabolites. Appl. Environ. Microb., v.63, p.4272-4281, 1997.

WETZSTEIN, H. G.; STADLER, M.; TICHY, H.; DALHOFF, A.; KARL, W. Degradation of ciprofloxacin by basidiomycetes and identification of metabolites $\mathrm{G}$ generated by the brown rot fungus Gloeophyllum striatum. Appl. Environ. Microb., v.65, p.1556-1563, 1999.
YUAN, F.; HU, CHUN.; HU, X.; WEI, D.; CHEN, Y.; Q, J. Photodegradation and toxicity changes of antibiotics in UV and $\mathrm{UV} / \mathrm{H}_{2} \mathrm{O}_{2}$ process. J. Hazard. Mater., v.185, p.12561263,2011

ZHANG, H.; HUANG, C-H. Oxidative transformation of fluoroquinolone antibacterial agents and structurally related amines by manganese oxide. Environ. Sci. Technol., v.39, p.4474-4483, 2005.

ZHANG, H.; HUANG, C-H. Adsorption and oxidation of fluoroquinolone antibacterial agents and structurally related amines with goethite. Chemosphere, v.66, p.1502-1512, 2007.

Received for publication on $01^{\text {st }}$ November 2012 Accepted for publication on $19^{\text {th }}$ September 2013 